\title{
Phytoplankton primary productivity around submarine groundwater discharge in nearshore coasts
}

\author{
Ryo Sugimoto ${ }^{1, *}$, Katsuhiro Kitagawa ${ }^{1}$, Saori Nishi ${ }^{1}$, Hisami Honda ${ }^{1,2}$, \\ Makoto Yamada ${ }^{2}$, Shiho Kobayashi ${ }^{3}$, Jun Shojii ${ }^{4}$, Shinji Ohsawa ${ }^{5}$, \\ Makoto Taniguchi ${ }^{2}$, Osamu Tominaga ${ }^{1}$ \\ ${ }^{1}$ Faculty of Marine Biosciences, Fukui Prefectural University, Obama, Fukui 917-0003, Japan \\ ${ }^{2}$ Research Institute for Humanity and Nature, Kyoto 603-8047, Japan \\ ${ }^{3}$ Field Science Education and Research Center, Kyoto University, Kyoto 606-0068, Japan \\ ${ }^{4}$ Graduate School of Biosphere Science, Hiroshima University, Hiroshima 739-8528, Japan \\ ${ }^{5}$ Institute for Geothermal Sciences, Kyoto University, Oita 874-0903, Japan
}

\begin{abstract}
Nutrients supplied from submarine groundwater discharge (SGD) are generally thought to enhance primary production in coastal seas. However, there is little evidence for a direct association between SGD and phytoplankton primary productivity. To elucidate the response of in situ primary productivity to SGD, we conducted comparative experiments at 3 coastal sites in Japan with different SGD types (Site A: Obama Bay; Site B: coast along the western foot of Mt. Chokai; Site C: Beppu Bay) during the summers of 2013-2015. At Site A, which is characterized by seepage-type SGD, we found a significant positive relationship between in situ primary productivity and ${ }^{222} \mathrm{Rn}$ concentration. This was likely driven by nutrient-limited water column conditions. On the other hand, at the volcanic coastal Sites B and C, which are dominated by spring-type SGD, no clear relationships between in situ primary productivity and ${ }^{222} \mathrm{Rn}$ concentration were found. Although significant relationships between nutrient concentrations and ${ }^{222} \mathrm{Rn}$ concentration suggest that SGD acts as a primary nutrient source in these regions, the non-trivial influence of light availability complicates those relationships. Furthermore, lower biomass-specific primary productivity around submarine springs at both sites suggests that submarine springs have negative impacts on phytoplankton growth rates around vent sites, possibly due to changes in local environmental conditions. Our study clarified that the mechanism by which SGD affects phytoplankton production differs from one ecosystem to another because of variable hydrogeographical properties, such as the type of groundwater discharge (i.e. spring or seepage).
\end{abstract}

KEY WORDS: In situ primary productivity $\cdot$ Submarine groundwater discharge $\cdot{ }^{222} \mathrm{Rn}$

\section{INTRODUCTION}

Trophic transfer of energy and essential biochemicals from phytoplankton biomass supports organisms of higher trophic levels in marine ecosystems. In coastal seas, terrestrial river runoff is one of the most important nutrient pathways sustaining phytoplankton primary production. However, groundwater is

*Corresponding author: sugiryo@fpu.ac.jp now recognized as an indispensable nutrient pathway from land to coastal seas (Burnett et al. 2006). Groundwater may play a significant role in coastal ecosystems despite the small water volume, because nutrient concentrations in groundwater are generally higher than in coastal waters (Valiela et al. 1990, Slomp \& Van Cappellen 2004). In some coastal locations, nutrient loading associated with groundwater

(C) The authors 2017. Open Access under Creative Commons by Attribution Licence. Use, distribution and reproduction are unrestricted. Authors and original publication must be credited. 
discharge is greater than that delivered by rivers (Valiela et al. 1992, Kim et al. 2005, Sugimoto et al. 2016).

The biological effects of nutrient inputs depend on their magnitudes as well as how and where the nutrients are supplied. Along nearshore coasts, nutrients delivered from submarine groundwater discharge (SGD) can have significant ecological impacts (Johannes 1980). Several studies have shown that nutrients transported via SGD are related to benthic and water-column primary production (Gobler \& SañudoWilhelmy 2001, Waska \& Kim 2011, Su et al. 2014). Nutrient addition bioassay experiments also support that SGD acts as a continual source of nutrients (Gob- ler \& Boneillo 2003, Lecher et al. 2015). However, there is little evidence for a direct association between SGD and in situ primary productivity. Moreover, its association may differ according to the type of groundwater discharge, because submarine seepage may be even more important volumetrically than submarine springs (Cable et al. 1996, Taniguchi et al. 2002).

In this study, we conducted field experiments at 3 coastal sites along the Japanese archipelago with different types of SGD (Site A: Obama Bay; Site B: the coast along the western foot of Mt. Chokai; and Site C: Beppu Bay; Fig. 1) to elucidate the influence of SGD on in situ phytoplankton primary productivity.
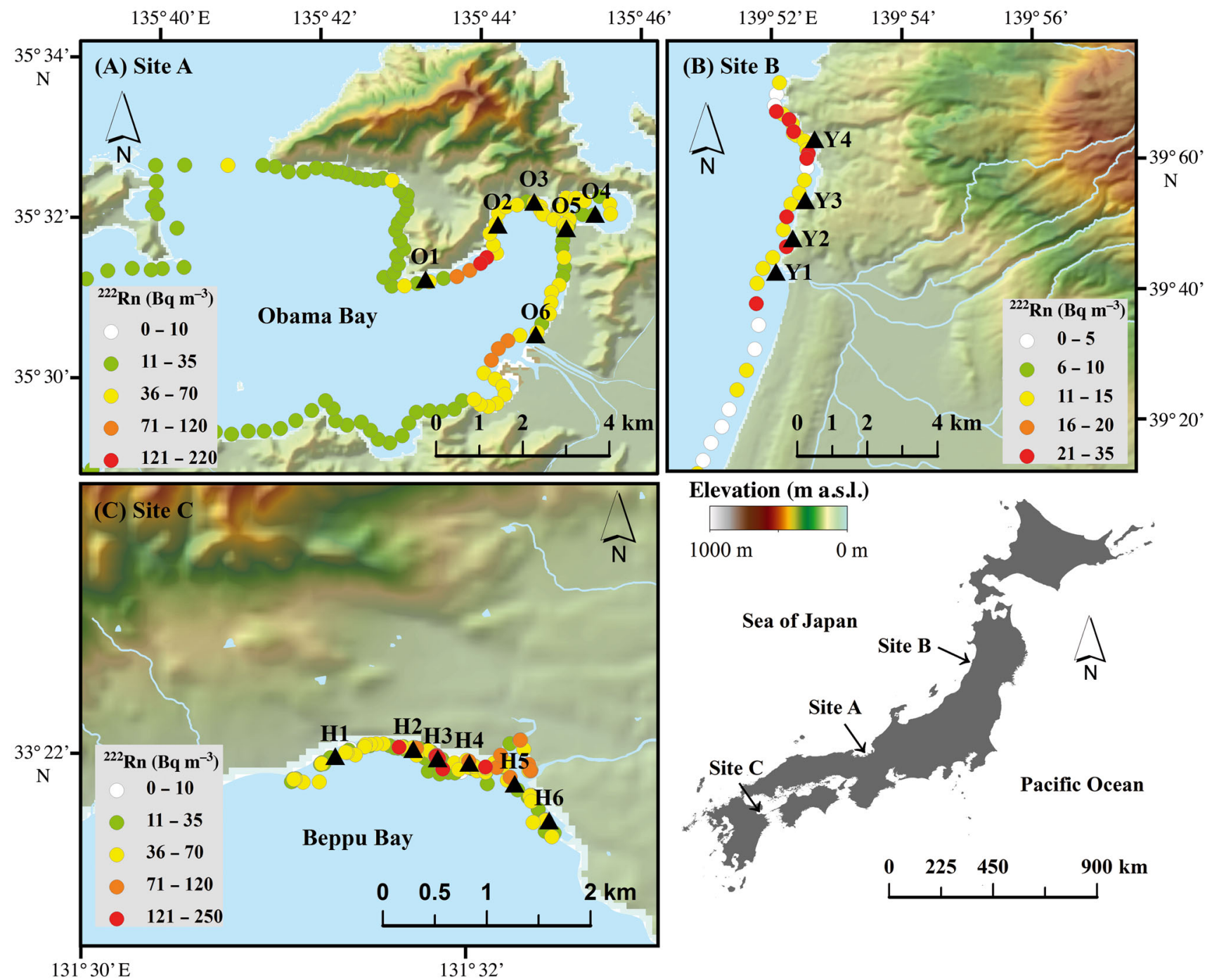

Fig. 1. Maps of the study areas with ${ }^{222} \mathrm{Rn}$ concentration plots in surface waters (depth $0.5-1.0 \mathrm{~m}$ from the surface). Field experiments for in situ primary productivity were conducted at (A) 6 stations within Obama Bay (Stns O1-O6), (B) 4 stations along the coast off the western foot of Mt. Chokai (Stns Y1-Y4), and (C) 6 stations along the coast of northern Beppu Bay (Stns $\mathrm{H} 1-\mathrm{H} 6) .{ }^{222} \mathrm{Rn}$ concentrations in surface waters were continuously monitored along the coast of Obama Bay, the coastal area off Mt. Chokai, and the northern coast of Beppu Bay 
First, we conducted continuous ${ }^{222} \mathrm{Rn}$ measurements at nearshore coasts to estimate the spatial variability in groundwater inputs. Radon and radium isotopes are generally used as natural tracers of SGD. Since they present an integrated signal as they enter the water column via SGD, their inventories can be used to estimate SGD rates (Burnett et al. 2006). In particular, ${ }^{222} \mathrm{Rn}$, with a half-life of $\sim 3.8 \mathrm{~d}$, is useful for identifying spatial variability in SGD environments in coastal seas where water residence time is short. We also compared in situ primary productivity at locations with different ${ }^{222} \mathrm{Rn}$ concentrations along each coast during the summer. Since phytoplankton primary productivity in coastal seas is generally determined by temperature and light availability as well as nutrient concentrations, we evaluated these limiting factors simultaneously during the incubation period.

\section{MATERIALS AND METHODS}

\section{Study sites}

Obama Bay (Site A) is a semi-enclosed embayment in central Japan (Fig. 1A). The Kita and Minami rivers empty into the eastern part of the bay; together, their watersheds encompass $72 \%$ of the bay's total watershed. Mean river discharge of both rivers is approx. $10 \mathrm{~m}^{3} \mathrm{~s}^{-1}$ (Sugimoto \& Tsuboi 2016). Within the watershed, there are significant groundwater resources on the alluvial plain. A recent study of the whole bay estimated that the percentage of SGD of the total terrestrial flux was highest ( $>40 \%$ ) during the summer, although SGD rates exhibited high intra-annual variability, with an average of 0.62 $\times 10^{-2} \mathrm{~m}^{3} \mathrm{~m}^{-2} \mathrm{~d}^{-1}$ (Sugimoto et al. 2016). In the eastern part of the bay, diffuse seepage along the shoreline and submarine seepage dominate the nutrient fluxes in nearshore coasts. The average SGD rate in this area is $8.3 \times 10^{-2} \mathrm{~m}^{3} \mathrm{~m}^{-2} \mathrm{~d}^{-1}$, with a spatiotemporal variability of 0.8 to $22.2 \times 10^{-2} \mathrm{~m}^{3} \mathrm{~m}^{-2} \mathrm{~d}^{-1}$. Fresh groundwater contributions to SGD fluxes are less than $6.3 \%$ (S. Kobayashi et al. unpubl.).

The Quaternary Chokai volcano is the highest peak in northern Japan (2236 m; Fig. 1B). Surface river water discharges are absent along the coastal area off the western foot of the mountain (Site B), except for along the southern edge. The topography of this coast is formed by andesitic lava flows that are oriented toward the sea (Hayashi \& Yamamoto 2008). Abundant freshwater submarine springs are present along this coastal area. The average SGD rate at
Kamaiso Bay (Stn Y2, Fig. 1B) was estimated to be $38.9 \times 10^{-2} \mathrm{~m}^{3} \mathrm{~m}^{-2} \mathrm{~d}^{-1}$, with a maximum value of 218 $\times 10^{-2} \mathrm{~m}^{3} \mathrm{~m}^{-2} \mathrm{~d}^{-1}$ (Hosono et al. 2012). Maximum contributions of fresh groundwater to SGD fluxes reached $20 \%$ (K. Ikuta et al. unpubl.). Hosono et al. (2012) suggested that the SGD rate in Mega Bay (Stn Y4, Fig 1B) was considerably higher than that in Kamaiso Bay.

The Kanagoe volcano group is a small Quaternary composite volcano with the highest peak at $623 \mathrm{~m}$, which is mainly comprised of pyroxene andesite (Fig. 1C). An alluvial fan and coast terrace are formed on the southeastern foot of this volcano. Several fresh submarine springs emerge from the rocky seabed along the nearshore coast of the Kanagoe volcano group in the northern part of Beppu Bay (Site C) Kono \& Tagawa 1996, Yamada et al. 2016). Although the SGD rate remains unclear, its magnitude is likely less than that at Site B.

\section{Field experiments}

To determine the locations of the stations to be used for the in situ incubation experiments, we continuously monitored ${ }^{222} \mathrm{Rn}$ concentration in surface waters (depth 0.5-1.0 m) at Site A on 13, 15, and 16 March 2013, at Site B on 7 June 2014, and at Site C on 26, 27, and 28 May 2014 (Fig. 1). We employed a multi-detector method (Dulaiova et al. 2005) using 3 radon detectors (RAD7, Durridge) at Site A and a dual-loop method (Dimova et al. 2009) at Sites B and $\mathrm{C}$ using one RAD7. The count uncertainties of the methods were $<30 \%$.

We then conducted comparative in situ primary productivity experiments at different ${ }^{222} \mathrm{Rn}$ concentration stations in summer. At Site A, we conducted the field experiments at 6 stations (depth 1.5-5 m) within the eastern part of the bay (Fig. 1A) on 26 July and 29 August, 2013 using a small boat. At Site B, experiments were conducted at 4 stations (depth $<2.0 \mathrm{~m}$ ) accessible from land on 10 June and 17 July 2014 (Fig. 1B). At Site C, experiments were conducted at 6 stations (depth 1.5-3.5 m) along the volcanic coast of Beppu Bay using a small boat on 29 July 2015 (Fig. 1C). The primary vents of submarine springs were around Stns Y2, Y4, and H3.

At each station, bottom water (50 or $20 \mathrm{~cm}$ above the floor) samples were collected using a $6 \mathrm{l}$ Van Dorn water sampler or a submersible pump and transferred to $2 \mathrm{l}$ polypropylene (PP) and three $1 \mathrm{l}$ polycarbonate (PC) incubation bottles. After adding $\mathrm{NaH}^{13} \mathrm{CO}_{3}$ to $3 \mathrm{PC}$ incubation bottles $(\sim 10 \%$ of the 
total inorganic carbon in ambient water), all bottles were incubated immediately for $2-4 \mathrm{~h}$ at each sampling depth (see Table 1). The incubations at each station were conducted simultaneously from 10:00 to 14:00 h. During the incubations, photon flux was measured at 10 min intervals using a photon logger (DEFI-L, JFE Advantech) at the same depth of each incubation bottle, and the data was averaged. For ${ }^{222} \mathrm{Rn}$ measurements, 3.51 glass bottles or 7.01 highdensity polyethylene bottles were filled and then sealed immediately to avoid gas loss. The residual water was filtered immediately for nutrient measurements.

In the laboratory, $100 \mathrm{ml}$ samples from the $21 \mathrm{PP}$ bottles were filtered through pre-combusted glassfiber filters ( $25 \mathrm{~mm}$ in diameter, Whatman GF/F). The filters were soaked separately in $5 \mathrm{ml} N, N$-dimethylformamide for subsequent chlorophyll a (chl a) analyses. Residual water samples in the PP bottles and 3 PC bottles were filtered through the Whatman $\mathrm{GF} / \mathrm{F}$ filters and stored individually in glass vials at $-30^{\circ} \mathrm{C}$ until subsequent isotope analysis.

\section{Chemical analysis}

Filters for natural and tracer ${ }^{13} \mathrm{C}$ analyses were stored overnight in individual desiccators using $\mathrm{HCl}$ fumes to remove the inorganic carbon. The $\delta^{13} \mathrm{C}$ values of natural particulate organic matter were measured using a mass spectrometer (Delta V Advantage, Thermo Fisher Scientific) and an elemental analyzer (Flash EA 1112, Thermo Fisher Scientific) and expressed in conventional delta notation (\%) relative to the Vienna PeeDee Belemnite standard. The reproducibility of $\delta^{13} \mathrm{C}$ exceeded $\pm 0.2 \%$. The enriched ${ }^{13} \mathrm{C}$ GF/F filters were analyzed using the Elementar Vario EL Cube or Micro Cube elemental analyzer (Elementar Analysensysteme) interfaced with the PDZ Europa 20-20 isotope ratio mass spectrometer (Sercon) at the University of California-Davis Stable Isotope Facility. Primary production was calculated according to Hama et al. (1983).

${ }^{222} \mathrm{Rn}$ concentration was measured according to Sugimoto et al. (2016). Briefly, sample bottles were aerated for $45 \mathrm{~min}$ at a room temperature, and then the equilibrated air in a closed air loop was measured by the RAD7 with at least 6 runs of $15 \mathrm{~min}$. The decay effect was corrected using the decay constant $\left(0.181 \mathrm{~d}^{-1}\right)$ and time elapsed after collection. The chl a concentration was quantified using a calibrated fluorometer (Trilogy, Turner Design). Concentrations of dissolved nitrate, nitrite, phosphate, and silicate were measured using an autoanalyzer (QuAAtro, BLTEC). The ammonium concentration was measured fluorometrically using the ortho-phthaldialdehyde method (Holmes et al. 1999) with the Trilogy fluorometer. We defined dissolved inorganic nitrogen (DIN) as the sum of nitrate, nitrite, and ammonium concentrations.

\section{Evaluation of limiting factors}

Limiting factors of in situ primary production can be evaluated using the equations of Steele (1962) for temperature $\left(F_{\mathrm{T}}\right)$ and light intensity $\left(F_{\mathrm{I}}\right)$ and the Michaelis-Menten equation for nutrients $\left(F_{\mathrm{N}}\right)$ as follows:

$$
\begin{gathered}
F_{\mathrm{T}}=T / T_{\mathrm{opt}} \times \exp \left(1-T / T_{\mathrm{opt}}\right) \\
F_{\mathrm{I}}=I / I_{\mathrm{opt}} \times \exp \left(1-I / I_{\mathrm{opt}}\right) \\
F_{\mathrm{N}}=\min \left[\mathrm{DIN} /\left(K_{\mathrm{N}}+\mathrm{DIN}\right), \mathrm{DIP} /\left(K_{\mathrm{P}}+\mathrm{DIP}\right)\right]
\end{gathered}
$$

where $T_{\text {opt }}\left(25^{\circ} \mathrm{C}\right)$ and $I_{\text {opt }}\left(419 \mu \mathrm{mol} \mathrm{m} \mathrm{m}^{-2} \mathrm{~s}^{-1}\right)$ are the optimum temperature and light for phytoplankton growth, respectively. $K_{\mathrm{N}}(1.7 \mu \mathrm{M})$ and $K_{\mathrm{P}}(0.19 \mu \mathrm{M})$ represent the half-saturation constants for DIN and dissolved inorganic phosphate (DIP), respectively. The above parameters were obtained from studies conducted on Japanese coasts (Yanagi \& Onitsuka 1999, Sugimoto et al. 2010). T, I, DIN, and DIP were based on observed temperature, light intensity, DIN, and DIP values at each station, respectively.

\section{RESULTS}

\section{Site A: Eastern part of Obama Bay}

The ${ }^{222} \mathrm{Rn}$ concentration showed spatial variations from 28 to $100 \mathrm{~Bq} \mathrm{~m}^{-3}$ in July 2013 and from 13 to 90 Bq m${ }^{-3}$ in August 2013 (Fig. 2A). Higher concentrations were measured at Stns O2 and O3. There was no clear spatial difference in salinity in July (32.4-32.9 psu), but salinity in August was considerably lower at Stn $\mathrm{O} 3$ (30.5 psu) than at the other stations (31.5-31.8 psu) (Table 1). The spatial variability in water temperature during both months was low (27.6-29.0 ${ }^{\circ} \mathrm{C}$ in July and $29.1-30.3^{\circ} \mathrm{C}$ in August). In situ primary productivity ranged from 11.0 to $49.5 \mu \mathrm{g}$

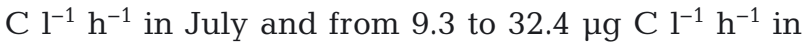
August 2013 (Fig. 2B). In situ primary productivity was correlated significantly with ${ }^{222} \mathrm{Rn}$ concentration $(\mathrm{r}=0.778, \mathrm{p}=0.003$, Fig. 3A). The concentrations of DIP and dissolved silicate (DSi) also showed signifi- 

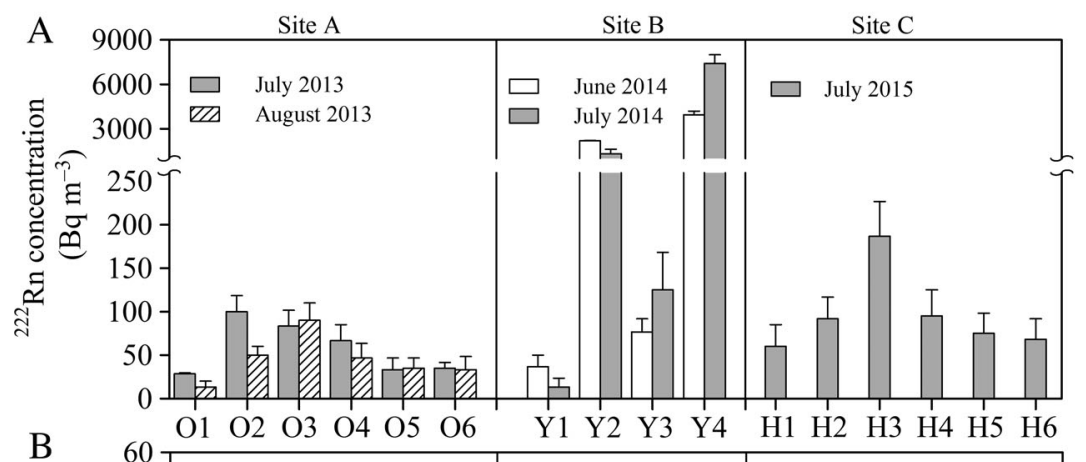

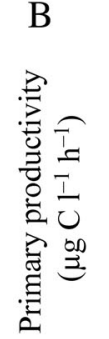
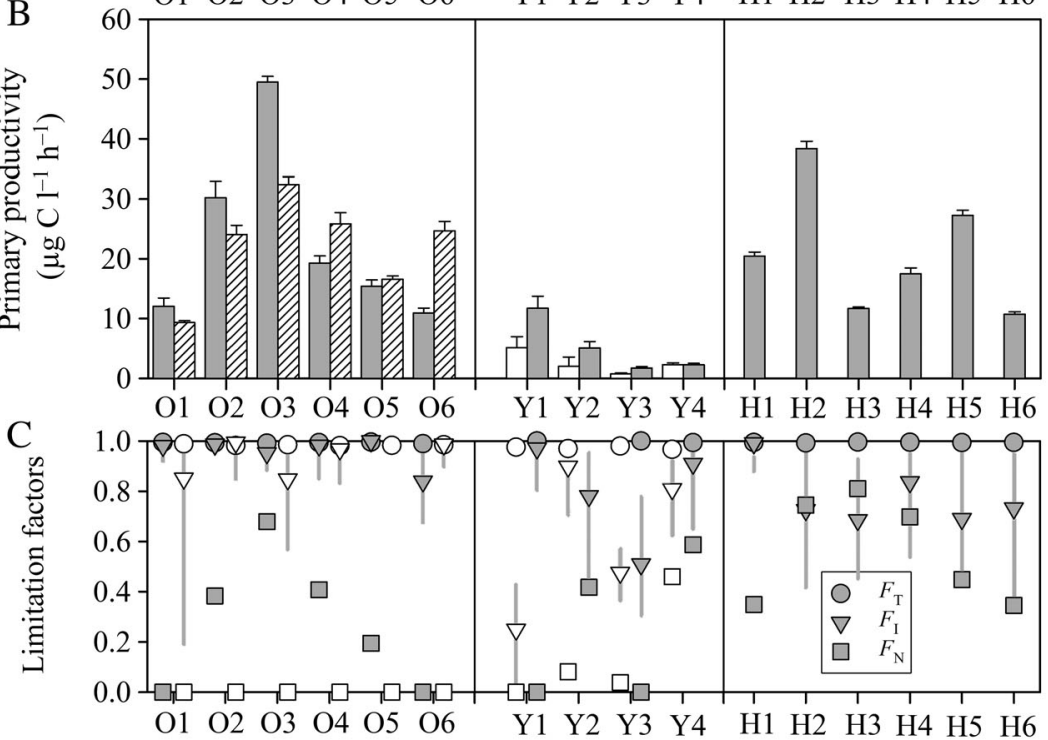

Fig. 2. (A) ${ }^{222} \mathrm{Rn}$ concentration, (B) in situ primary productivity and (C) limitation factors at each site. Error bars are standard deviations of repeated ${ }^{222} \mathrm{Rn}$ measurements and triplicate samples of in situ primary productivity. $F_{\mathrm{T}}=$ limitation factor for temperature, $F_{\mathrm{I}}=$ limitation factor for light and $F_{\mathrm{N}}=$ limitation factor for nutrients. Grey lines are standard deviations for light. Closed and open symbols at Site A are July and August 2013, respectively. Open and closed symbols at Site B are June and July 2014, respectively spring sites (Stns Y1 and Y3) during both months (Table 1). In situ primary productivity ranged from 0.8 to $5.2 \mu \mathrm{g}$ $\mathrm{C}^{-1} \mathrm{~h}^{-1}$ in June 2014 and from 1.8 to

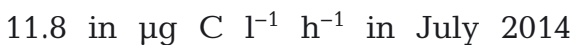
(Fig. 2B), whereas there was no significant relationship between in situ primary productivity and ${ }^{222} \mathrm{Rn}$ concentration ( $\mathrm{r}=0.323, \mathrm{p}=0.436$; Fig. 3A). The highest values during each month were documented at Stn Y1 near the river mouth. The concentrations of DIN, DIP, and DSi were correlated positively with ${ }^{222} \mathrm{Rn}$ concentration ( $\mathrm{r}$ $>0.81, \mathrm{p}<0.02$; Fig. 3B-D). Although $F_{\mathrm{N}}$ showed the lowest values compared to other limitation factors, submarine springs mitigated the nutrient limitation at Stns Y2 and Y4 (Fig. 2C).

\section{Site C: Northern part of Beppu Bay}

In July 2015, ${ }^{222} \mathrm{Rn}$ concentration along the northern coast of Beppu Bay ranged from 60 to $187 \mathrm{~Bq} \mathrm{~m}^{-3}$ (Fig. 2A). The maximum concentration was observed at Stn H3 near submarine springs. Salinity was lowest at Stn H3 (26.2 psu, Table 1), although there was no significant relationship between ${ }^{222} \mathrm{Rn}$ concentration and salinity. The spatial variability in water temperature was low $\left(27.6-28.4^{\circ} \mathrm{C}\right)$. In situ primary productivity ranged from 10.7 to $38.4 \mu \mathrm{g} \mathrm{C}^{-1} \mathrm{~h}^{-1}$, but cant relationships with ${ }^{222} \mathrm{Rn}$ concentration ( $\mathrm{r}>0.66$, $p<0.02$, Fig. 3C,D), whereas no significant relationship between ${ }^{222} \mathrm{Rn}$ and the DIN concentration was observed $(\mathrm{r}=0.572, \mathrm{p}=0.052$, Fig. $3 \mathrm{~B}) . F_{\mathrm{N}}$ values were lower than the other 2 factors, although $F_{\mathrm{N}}$ at Stn O3 in July 2013 increased to 0.68 (Fig. 2C).

\section{Site B: Coastal region of Mt. Chokai}

The ${ }^{222} \mathrm{Rn}$ concentrations at Stns Y2 and Y4 near submarine springs were markedly high (1320$7410 \mathrm{~Bq} \mathrm{~m}^{-3}$ ), whereas those at the other stations were much lower $\left(<130 \mathrm{~Bq} \mathrm{~m}^{-3}\right.$; Fig. 2A). Moreover, we observed noticeable decreases in water temperature $\left(\sim 3^{\circ} \mathrm{C}\right)$ and salinity $(\sim 3 \mathrm{psu})$ around the submarine springs (Stns Y2 and Y4) compared with no- there was no clear relationship between ${ }^{222} \mathrm{Rn}$ and in situ primary productivity $(\mathrm{r}=0.304, \mathrm{p}=0.558$; Fig. $3 \mathrm{~A})$. On the other hand, significant linear relationships were observed between ${ }^{222} \mathrm{Rn}$ concentration and both DIN and DIP concentrations ( $\mathrm{r}>0.90, \mathrm{p}<$ 0.02 ; Fig. 3B,C), but not the DSi concentration $(r=$ $0.785, \mathrm{p}=0.064 ;$ Fig. 3D). The values of $F_{\mathrm{N}}$ at Stns H2, $\mathrm{H} 3$ and $\mathrm{H} 4$ were similar to those of $F_{\mathrm{I}}$ (Fig. 2C).

\section{DISCUSSION}

Primary productivity is the product of phytoplankton biomass and phytoplankton growth rate. The former is regulated by import, export, mortality, nutrient supply, and growth rate, while the latter is regulated by light, temperature, and nutrient concentrations 
Table 1. Summary of environmental parameters and in situ primary productivity (PP). Uncertainties of ${ }^{222} \mathrm{Rn}$, photon flux and PP are based on the standard deviation for repeated measurements, 10 min interval measurments and triplicate samples, respectively. DIN: dissolved inorganic nitrogen; DIP: dissolved inorganic phosphate; DSi: dissolved silicate

\begin{tabular}{|c|c|c|c|c|c|c|c|c|c|c|}
\hline Stn & $\begin{array}{l}\text { Incubation depth } \\
\text { (water depth) (m) }\end{array}$ & $\begin{array}{c}{ }^{222} \mathrm{Rn} \\
\left(\mathrm{Bq} \mathrm{m} \mathrm{m}^{-3}\right)\end{array}$ & $\begin{array}{l}\text { Photon flux } \\
\left(\mu \mathrm{mol} \mathrm{m} \mathrm{m}^{-2} \mathrm{~s}^{-1}\right)\end{array}$ & $\begin{array}{l}\text { Temp. } \\
\left({ }^{\circ} \mathrm{C}\right)\end{array}$ & Salinity & $\begin{array}{l}\text { DIN } \\
(\mu \mathrm{M})\end{array}$ & $\begin{array}{l}\text { DIP } \\
(\mu \mathrm{M})\end{array}$ & $\begin{array}{c}\mathrm{DSi} \\
(\mu \mathrm{M})\end{array}$ & $\begin{array}{c}\text { Chl a } \\
\left(\mu \mathrm{g} \mathrm{l}^{-1}\right)\end{array}$ & 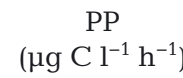 \\
\hline \multicolumn{11}{|c|}{ Site A: 26 July 2013} \\
\hline $\mathrm{O} 1$ & $4.8(5.3)$ & $28 \pm 1$ & $506 \pm 106$ & 27.8 & 32.8 & 0.06 & $<0.05$ & 20.85 & 4.2 & $12.1 \pm 1.4$ \\
\hline $\mathrm{O} 2$ & $3.0(3.5)$ & $100 \pm 18$ & $493 \pm 75$ & 28.2 & 32.9 & 1.05 & 0.47 & 33.82 & 8.8 & $30.2 \pm 2.8$ \\
\hline $\mathrm{O} 3$ & $1.7(2.2)$ & $83 \pm 18$ & $564 \pm 98$ & 28.6 & 32.8 & 3.59 & 0.84 & 41.47 & 9.9 & $49.5 \pm 1.0$ \\
\hline $\mathrm{O} 4$ & $3.2(3.7)$ & $67 \pm 18$ & $344 \pm 120$ & 28.1 & 32.9 & 1.17 & 0.39 & 26.88 & 8.3 & $19.3 \pm 1.2$ \\
\hline O5 & $3.3(3.8)$ & $33 \pm 13$ & $416 \pm 30$ & 27.6 & 32.9 & 0.41 & 0.07 & 20.24 & 5.3 & $15.4 \pm 1.0$ \\
\hline O6 & $1.5(2.0)$ & $35 \pm 7$ & $718 \pm 189$ & 29.0 & 32.4 & 1.38 & $<0.05$ & 6.01 & 2.8 & $11.0 \pm 0.8$ \\
\hline \multicolumn{11}{|c|}{ Site A: 29 August 2013} \\
\hline $\mathrm{O} 1$ & $4.7(5.2)$ & $13 \pm 7$ & $224 \pm 192$ & 29.1 & 31.5 & 0.25 & $<0.05$ & 1.43 & 2.6 & $9.3 \pm 0.3$ \\
\hline $\mathrm{O} 2$ & $2.9(3.4)$ & $50 \pm 10$ & $377 \pm 154$ & 30.2 & 31.8 & 0.07 & $<0.05$ & 12.34 & 12.9 & $24.1 \pm 1.5$ \\
\hline $\mathrm{O} 3$ & $1.0(1.5)$ & $90 \pm 20$ & $707 \pm 326$ & 29.7 & 30.5 & 0.90 & $<0.05$ & 19.13 & 3.9 & $32.4 \pm 1.3$ \\
\hline O4 & $3.2(3.7)$ & $47 \pm 17$ & $320 \pm 106$ & 30.3 & 31.8 & 0.75 & $<0.05$ & 9.02 & 12.1 & $25.9 \pm 1.9$ \\
\hline O5 & $3.3(3.8)$ & $35 \pm 12$ & - & 30.0 & 31.8 & 0.07 & $<0.05$ & 14.03 & 6.4 & $16.6 \pm 0.6$ \\
\hline O6 & $2.2(2.7)$ & $33 \pm 15$ & $491 \pm 153$ & 29.7 & 31.7 & 0.12 & $<0.05$ & 7.28 & 4.8 & $24.7 \pm 1.5$ \\
\hline \multicolumn{11}{|c|}{ Site B: 10 June 2014} \\
\hline $\mathrm{Y} 1$ & $1.5(2.0)$ & $37 \pm 13$ & $42 \pm 38$ & 19.8 & 33.9 & 0.06 & $<0.05$ & 0.50 & 1.9 & $5.2 \pm 1.8$ \\
\hline $\mathrm{Y} 2$ & $0.4(0.6)$ & $2180 \pm 33$ & $254 \pm 95$ & 19.2 & 30.7 & 2.68 & $<0.05$ & 2.18 & 7.2 & $2.0 \pm 1.5$ \\
\hline Y3 & $0.6(1.1)$ & $77 \pm 15$ & $91 \pm 25$ & 20.2 & 33.3 & 0.98 & $<0.05$ & 0.48 & 1.3 & $0.8 \pm 0.2$ \\
\hline Y4 & $0.4(0.6)$ & $3950 \pm 240$ & $202 \pm 70$ & 19.0 & 30.1 & 6.77 & 0.16 & 2.65 & 2.5 & $2.3 \pm 0.3$ \\
\hline \multicolumn{11}{|c|}{ Site B: 17 July 2014} \\
\hline $\mathrm{Y} 1$ & $1.2(1.7)$ & $13 \pm 10$ & $530 \pm 228$ & 24.8 & 31.3 & 0.51 & $<0.05$ & $<0.1$ & 2.0 & $11.8 \pm 2.0$ \\
\hline Y2 & $0.4(0.6)$ & $1320 \pm 300$ & $189 \pm 113$ & 22.0 & 26.5 & 11.61 & 0.14 & 2.31 & 3.4 & $5.1 \pm 1.1$ \\
\hline Y3 & $0.6(0.8)$ & $125 \pm 43$ & $1110 \pm 320$ & 24.4 & 30.9 & 1.35 & $<0.05$ & 0.67 & 0.8 & $1.8 \pm 0.2$ \\
\hline Y4 & $0.3(0.5)$ & $7410 \pm 570$ & $262 \pm 122$ & 22.2 & 26.9 & 14.94 & 0.27 & 2.80 & 6.2 & $2.3 \pm 0.3$ \\
\hline \multicolumn{11}{|c|}{ Site C: 29 July 2015} \\
\hline H1 & $1.8(2.3)$ & $60 \pm 25$ & $476 \pm 192$ & 27.8 & 28.5 & 0.91 & 0.27 & 1.47 & 7.2 & $20.5 \pm 0.7$ \\
\hline $\mathrm{H} 2$ & $1.0(1.5)$ & $92 \pm 25$ & $850 \pm 389$ & 28.4 & 27.1 & 9.80 & 0.56 & 3.46 & 9.1 & $38.4 \pm 1.2$ \\
\hline H3 & $3.0(3.5)$ & $187 \pm 40$ & $895 \pm 292$ & 27.6 & 26.2 & 14.71 & 0.81 & 3.67 & 5.8 & $11.7 \pm 0.2$ \\
\hline $\mathrm{H} 4$ & $1.5(2.0)$ & $95 \pm 30$ & $721 \pm 351$ & 27.7 & 27.7 & 7.15 & 0.44 & 2.34 & 3.5 & $17.5 \pm 1.0$ \\
\hline H5 & $2.5(3.0)$ & $75 \pm 23$ & $891 \pm 347$ & 28.0 & 29.5 & 1.38 & 0.21 & 1.58 & 7.2 & $27.2 \pm 0.9$ \\
\hline $\mathrm{H} 6$ & $1.5(2.0)$ & $68 \pm 23$ & $842 \pm 545$ & 27.8 & 30.3 & 0.90 & 0.15 & 0.99 & 2.6 & $10.7 \pm 0.4$ \\
\hline
\end{tabular}

(Cloern et al. 2014). At Site A, the spatial pattern of in situ primary productivity corresponded to that of ${ }^{222} \mathrm{Rn}$ concentration (Fig. 3A). The maximum rates of phytoplankton primary production at Stn $\mathrm{O} 3(49.5 \mu \mathrm{g}$ $\mathrm{C}^{-1} \mathrm{~h}^{-1}$ in July and $32.4 \mu \mathrm{g} \mathrm{C} \mathrm{l}^{-1} \mathrm{~h}^{-1}$ in August), where ${ }^{222} \mathrm{Rn}$ was highest, were roughly 4 -fold higher than those at Stn O1, where ${ }^{222} \mathrm{Rn}$ concentration was lowest (Fig. 2B). These values exceeded the in situ primary productivity observed at the Seto Inland Sea, Japan (0.4-32.1 $\mu \mathrm{g} \mathrm{C}^{-1} \mathrm{~h}^{-1}$; Tada et al. 1998), which is a eutrophic region with frequent summertime red tide events. Moreover, biomass-specific primary productivity $\left(P_{\mathrm{B}}, \mu \mathrm{g} \mathrm{C} \mu \mathrm{g} \mathrm{chl} a^{-1} \mathrm{~h}^{-1}\right)$ at Stn O3 was highest in July and August (5.0 and $8.3 \mu \mathrm{g} \mathrm{C} \mathrm{\mu g}^{-1} \mathrm{chl} \mathrm{a}^{-1}$ $\mathrm{h}^{-1}$, respectively), whereas $P_{\mathrm{B}}$ values at other stations were $<5 \mu \mathrm{g} \mathrm{C} \mu \mathrm{g} \mathrm{chl} a^{-1} \mathrm{~h}^{-1}$ (Fig. 4). This suggests that the high phytoplankton growth rate resulted in higher primary productivity. Considering that the phytoplankton growth rate was limited primarily by nutrient concentrations $\left(F_{\mathrm{N}}<0.68\right.$ and $<0.05$ in July and August 2013, respectively; Fig. 2C), nutrient supply via SGD would likely enhance primary productivity. The lack of a linear relationship between ${ }^{222} \mathrm{Rn}$ concentration and the DIN concentration, in contrast to DIP and DSi concentrations (Fig. 3), suggests that nutrients delivered through submarine groundwater seepage may be assimilated instantaneously by phytoplankton under nitrogen-limited conditions. However, a non-negligible positive relationship between photon flux and $P_{\mathrm{B}}$ values $(\mathrm{r}=0.671, \mathrm{p}=0.024)$ complicated the potential importance of light irradiance on in situ primary productivity. Further study is needed to resolve the irradiance issue.

Volcanic mountain coastlines worldwide have a high potential for SGD (Kim et al. 2003, Hwang et al. 2005). At the nearshore coasts adjacent to Mt. Chokai 

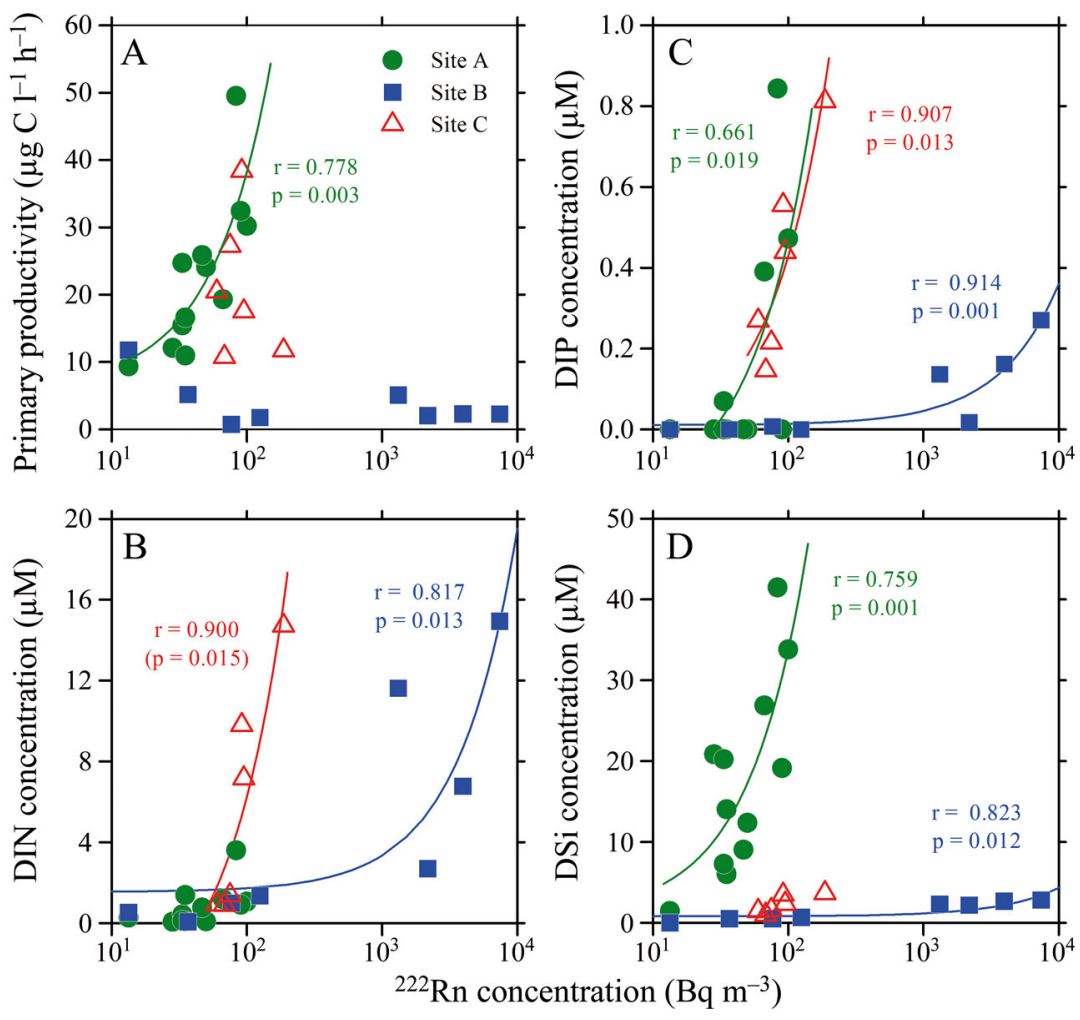

Fig. $3 .{ }^{222} \mathrm{Rn}$ concentration vs. (A) in situ primary productivity, (B) DIN concentrations, (C) DIP concentrations, and (D) DSi concentrations at each site. Regression lines show significant relationships $(\mathrm{p}<0.05)$

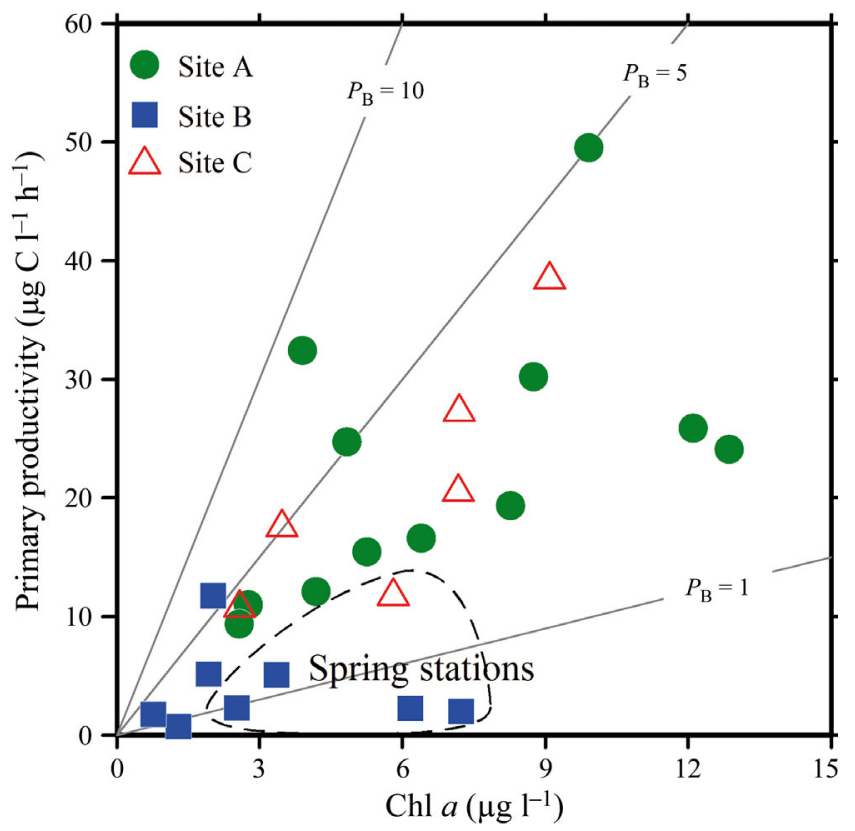

Fig. 4. Relationship between chl a concentrations and in situ primary productivity at each site. Solid lines are biomassspecific primary productivity $\left(P_{\mathrm{B}}, \mu \mathrm{g} \mathrm{C} \mu \mathrm{g} \mathrm{Chl} \mathrm{a}^{-1} \mathrm{~h}^{-1}\right)$. Dashed enclosure represents stations around submarine springs at Sites B and C (Stns Y2, Y4, and H3)
(Site B) and Mt. Kanagoe (Site C), spatial patterns of nutrient concentrations corresponded to those of ${ }^{222} \mathrm{Rn}$ concentration (Fig. 3B-D). These findings indicate that SGD provides a significant source of allochthonous nutrients into coastal waters. Therefore, SGD appears to play a role in driving phytoplankton production. However, spatial patterns of in situ primary productivity in these areas could not be determined by SGD nutrient contributions (Fig. 3A). Although this was due partly to the nontrivial influences of light availability $\left(F_{I}=0.25-0.97\right.$ and $0.69-0.99$ at Sites B and C, respectively) as well as nutrient concentrations $\left(F_{\mathrm{N}}=0.01-\right.$ 0.59 and $0.35-0.81$ at Sites B and C, respectively; Fig. 2C), the difference in hydrographic properties (i.e. submarine springs) may also be related to this unexpected result.

At Site B, SGD mitigated nutrientlimited conditions at the stations around submarine springs, but nutrient concentrations were the primary factor limiting phytoplankton growth rates (Fig. 2C). Hosono et al. (2012) noted that SGD at Site B provides a favorable nutrient balance for phytoplankton uptake because the Redfield ratio is closer to the DIN:DIP ratio in groundwater (16.6) than in river water (33.3). However, we did not find a positive association between SGD and in situ primary productivity (Fig. $3 \mathrm{~A})$, and the lower $P_{\mathrm{B}}$ values around submarine springs relative to the other stations (Fig. 4) suggested lower phytoplankton growth rates. Note that the SGD rates at Stn Y2 reached roughly $200 \times 10^{-2}$ $\mathrm{m}^{3} \mathrm{~m}^{-2} \mathrm{~d}^{-1}$ (Hosono et al. 2012) and fresh groundwater contributed about $20 \%$ of the SGD (K. Ikuta unpubl.). Furthermore, the SGD rate at Stn Y4 was more significant $\left(\sim 310 \times 10^{-2} \mathrm{~m}^{3} \mathrm{~m}^{-2} \mathrm{~d}^{-1}\right.$, Hosono et al. 2012). These estimates suggest that this location is characterized by a SGD rate which is much higher than in many other areas of the world (Taniguchi et al. 2002). The high SGD rates altered water temperature and salinity at Stns Y2 and Y4 considerably, compared to low SGD sites (Stns Y1 and Y3) (Table 1). Drastic changes in the water column conditions driven by fresh SGD may be an unfavorable condition for phytoplankton primary production. Further study is needed to elucidate local impacts of submarine springs on phytoplankton production. 
In comparison, at Site $\mathrm{C}$, the in situ primary productivity and $P_{\mathrm{B}}$ values were lower around the submarine springs at Stn $\mathrm{H} 3\left(11.7 \mu \mathrm{g} \mathrm{C} \mathrm{l}^{-1} \mathrm{~h}^{-1}\right.$ and $2.0 \mu \mathrm{g}$ $\mathrm{C} \mu \mathrm{g} \mathrm{chl} \mathrm{a}^{-1} \mathrm{~h}^{-1}$, respectively) than at the surrounding stations, Stns H2 and H4 (17.5-38.4 $\mu \mathrm{g} \mathrm{C}^{-1} \mathrm{~h}^{-1}$ and 4.2-5.0 $\mu \mathrm{g} \mathrm{C} \mu \mathrm{g} \mathrm{chl} \mathrm{a}^{-1} \mathrm{~h}^{-1}$, respectively) (Figs. 2B \& 4). Because the $F_{\mathrm{N}}$ and $F_{\mathrm{I}}$ values at $\mathrm{Stn} \mathrm{H} 3$ were similar to those at Stns $\mathrm{H} 2$ and H4 (Fig. 2C), the lower $P_{\mathrm{B}}$ value at Stn $\mathrm{H} 3$ does not seem to be affected by low light intensity or low nutrient concentrations.

Freshwater input via rivers functions as both a nutrient source that promotes phytoplankton growth rates and a transport process that can prevent phytoplankton accumulation within estuaries (Cloern et al. 2014). In some estuaries, the maximum phytoplankton biomass is associated with older water masses (approx. $10 \mathrm{~d}$ of age or flushing times; Peierls et al. 2012, Tomasky-Holmes et al. 2013), while abundant nitrate is found under optimum flushing times (Peierls et al. 2012). Our findings suggest that nutrients delivered via submarine springs are not used efficiently by phytoplankton, possibly due to lower residence times. The link among ${ }^{222} \mathrm{Rn}$, in situ primary productivity, and the flushing time must be clarified in future studies.

In conclusion, our comparative and simultaneous experimental studies provide clear and unprecedented evidence for a direct association between SGD and coastal primary production, despite limitations associated with the sampling design (i.e. limited sampling times and lack of SGD rate and nutrient flux measurements). The mechanisms by which SGD affects phytoplankton production differ from one ecosystem to another depending on hydrogeographical properties, such as type of groundwater discharge (i.e. spring or seepage), and are complex and difficult to distinguish. Compared with the rapid nutrient supply afforded by submarine springs, nutrients delivered via submarine groundwater seepage may be efficiently used by phytoplankton in nearshore coasts. These findings represent an important step toward clarifying the ecological importance of SGD. More extensive studies coupled with kinetic and quantitative indices of phytoplankton production and SGD, as well as nutrient bioassay experiments, are needed to confirm the influence of nutrient transport via SGD on primary production.

Acknowledgements. This work was financially supported by JSPS KAKENHI Grant Number 16H06200 and the Research Project 'Human-Environmental Security in Asia-Pacific Ring of Fire: Water-Energy-Food Nexus (R-08-Init)' at the Research Institute for Humanity and Nature.

\section{LITERATURE CITED}

Burnett WC, Aggarwal PK, Aureli A, Bokuniewicz H and others (2006) Quantifying submarine groundwater discharge in the coastal zone via multiple methods. Sci Total Environ 367:498-543

* Cable JE, Bugna GC, Burnett WC, Chanton JP (1996) Application of ${ }^{222} \mathrm{Rn}$ and $\mathrm{CH}_{4}$ for assessment of groundwater discharge to the coastal ocean. Limnol Oceanogr 41: 1347-1353

Cloern JE, Foster SQ, Kleckner AE (2014) Phytoplankton primary production in the world's estuarine-coastal ecosystems. Biogeosciences 11:2477-2501

Dimova N, Burnett WC, Lane-Smith D (2009) Improved automated analysis of radon $\left({ }^{222} \mathrm{Rn}\right)$ and thoron $\left({ }^{220} \mathrm{Rn}\right)$ in natural waters. Environ Sci Technol 43:8599-8603

* Dulaiova H, Peterson R, Burnett WC, Lane-Smith D (2005) A multi-detector continuous monitor for assessment of ${ }^{222} \mathrm{Rn}$ in the coastal ocean. J Radioanal Nucl Chem 263: 361-363

Gobler CJ, Boneillo GE (2003) Impacts of anthropogenically influenced groundwater seepage on water chemistry and phytoplankton dynamics within a coastal marine system. Mar Ecol Prog Ser 255:101-114

Gobler CJ, Sañudo-Wilhelmy SA (2001) Temporal variability of groundwater seepage and brown tide blooms in a Long Island embayment. Mar Ecol Prog Ser 217: 299-309

Hama T, Miyazaki T, Ogawa Y, Iwakuma T, Takahashi M, Otsuki A, Ichimura S (1983) Measurement of photosynthetic production of a marine phytoplankton population using a stable ${ }^{13} \mathrm{C}$ isotope. Mar Biol 73:31-36

*Hayashi S, Yamamoto M (2008) Chokai volcano. J Geol Soc Japan 114:S87-S95 (in Japanese)

*Holmes RM, Aminot A, Kérouel R, Hooker BA, Peterson BJ (1999) A simple and precise method for measuring ammonium in marine and freshwater ecosystems. Can J Fish Aquat Sci 56:1801-1808

*Hosono T, Ono M, Burnett WC, Tokunaga T, Taniguchi M, Akimichi T (2012) Spatial distribution of submarine groundwater discharge and associated nutrients within a local coastal area. Environ Sci Technol 46:5319-5326

*Hwang D, Lee YW, Kim G (2005) Large submarine groundwater discharge and benthic eutrophication in Bangdu Bay on volcanic Jeju Island, Korea. Limnol Oceanogr 50: 1393-1403

Johannes RE (1980) Ecological significance of the submarine discharge of groundwater. Mar Ecol Prog Ser 3:365-373

Kim G, Lee KK, Park KS, Hwang DW, Yang HS (2003) Large submarine groundwater discharge (SGD) from a volcanic island. Geophys Res Lett 30:2098

Kim G, Ryu JW, Yang HS, Yun ST (2005) Submarine groundwater discharge (SGD) into the Yellow Sea revealed by ${ }^{228} \mathrm{Ra}$ and ${ }^{226} \mathrm{Ra}$ isotopes: implications for global silicate fluxes. Earth Planet Sci Lett 237:156-166

Kono T, Tagawa T (1996) Submarine springs and groundwater study of Hiji-town in Oita Prefecture. Bull Nippon Bunri Univ 24:103-109 (in Japanese with English abstract)

ㄴocher AL, Mackey K, Kudela R, Ryan J, Fisher A, Murray J, Paytan A (2015) Nutrient loading through submarine groundwater discharge and phytoplankton growth in Monterey Bay, CA. Environ Sci Technol 49:6665-6673

* Peierls BL, Hall NS, Paerl HW (2012) Non-monotonic responses of phytoplankton biomass accumulation to 
hydrologic variability: a comparison of two coastal plain North Carolina estuaries. Estuaries Coasts 35:1376-1392

Slomp CP, Van Cappellen P (2004) Nutrient inputs to the coastal ocean through submarine groundwater discharge: controls and potential impact. J Hydrol 295: 64-86

Steele JH (1962) Environmental control of photosynthesis in the sea. Limnol Oceanogr 7:137-150

* Su N, Burnett WC, MacIntyre HL, Liefer JD, Peterson RN, Viso R (2014) Natural radon and radium isotopes for assessing groundwater discharge into Little Lagoon, AL: implications for harmful algal blooms. Estuaries Coasts 37:893-910

Sugimoto R, Tsuboi T (2016) Seasonal and annual fluxes of atmospheric nitrogen deposition and riverine nitrogen export in two adjacent rivers in central Japan facing the Sea of Japan. J Hydrol Reg Stud, doi:10.1016/j.ejrh. 2015.11.019

Sugimoto R, Kasai A, Miyajima T, Fujita K (2010) Modeling phytoplankton production in Ise Bay, Japan: use of nitrogen isotopes to identify dissolved inorganic nitrogen sources. Estuar Coast Shelf Sci 86:450-466

Sugimoto R, Honda H, Kobayashi S, Takao Y, Tahara D, Tominaga O, Taniguchi M (2016) Seasonal changes in submarine groundwater discharge and associated nutrient transport into a tideless semi-enclosed embayment (Obama Bay, Japan). Estuaries Coasts 39:13-26

Tada K, Monaka K, Morishita M, Hashimoto T (1998) Standing stocks and production rates of phytoplankton and

Editorial responsibility: Graham Savidge,

Portaferry, UK abundance of bacteria in the Seto Inland Sea, Japan. J Oceanogr 54:285-295

Taniguchi M, Burnett WC, Cable JE, Turner JV (2002) Investigation of submarine groundwater discharge. Hydrol Processes 16:2115-2129

Tomasky-Holmes G, Valiela I, Charette MA (2013) Determination of water mass ages using radium isotopes as tracers: implications for phytoplankton dynamics in estuaries. Mar Chem 156:18-26

* Valiela I, Costa J, Foreman K, Teal J, Howes B, Aubrey D (1990) Transport of groundwater-borne nutrients from watersheds and their effects on coastal waters. Biogeochemistry 10:177-197

Valiela I, Foreman K, LaMontagne M, Hersh D and others (1992) Couplings of watersheds and coastal waters: sources and consequences of nutrient enrichment in Waquiot Bay, Massachusetts. Estuaries 15:443-457

Waska H, Kim G (2011) Submarine groundwater discharge (SGD) as a main nutrient source for benthic and watercolumn primary production in a large intertidal environment of the Yellow Sea. J Sea Res 65:103-113

* Yamada M, Shoji J, Teramoto S, Ohsawa S and others (2016) Exploration of submarine groundwater discharge using a drone in a coastal area of Hiji town, Oita Prefecture, Japan in summer. J Jpn Assoc Hydrol Sci 46:29-38 (in Japanese with English abstract)

Yanagi T, Onitsuka G (1999) Numerical model on the lower trophic level ecosystem in Hakata Bay. Umi-no-Kenkyu 8:245-251 (in Japanese with English abstract)

Submitted: June 13, 2016; Accepted: November 9, 2016 Proofs received from author(s): January 13, 2017 